\title{
HARMONISASI PENGATURAN TENTANG KEWENANGAN DALAM PENERBITAN SURAT PERSETUJUAN BERLAYAR (SPB) KAPAL IKAN DI PELABUHAN BELAWAN DITINJAU DARI UNDANG-UNDANG NOMOR 17 TAHUN 2008 TENTANG PELAYARAN DAN UNDANG- UNDANG NOMOR 45 TAHUN 2009 TENTANG PERIKANAN
}

\author{
Muhammad Said Sitompul \\ Kesyahbandaran Utama Belawan \\ Sitompul.said@gmail.com
}

\begin{abstract}
ABSTRAK
Harmonisasi pengaturan tentang kompetensi (kewenangan) dalam Penerbitan Surat Persetujuan Berlayar Kapal Ikan di Pelabuhan Belawan ditinjau dari UU.Nomor 17 Tahun 2008 dengan UU Nomor 45 Tahun 2009, khususnya ketentuan Pasal 42 UU No. 45 Tahun 2009 terkait kewenangan Syahbandar dalam penerbitan Surat Persetujuan Berlayar, bahwa terjadi ketidakharmonisan (disharmonisasi) peraturan perundang-undangan antara UU 17 Tahun 2008 dengan UU. No. 45 Tahun 2009, serta termasuk peraturan di bawahnya. Selanjutnya keabsahan (legitimasi) Surat Persetujuan Berlayar yang diterbitkan oleh Syahbandar Perikanan di Pelabuhan Belawan, adalah sah menurut UU No. 45 Tahun 2009, tetapi bertentangan dengan UU No. 12 Tahun 2011 tentang Pembentukan Peraturan Perundang-undangan sangatlah bertentangan dengan azas hukum pembentukan undangundang (azas legal drafting). Tanggung jawab hukum syahbandar di pelabuhan perikanan tidak sepenuhnya bertanggung jawab atas terjadinya kecelakaan kapal ikan karena didalam undang-undangnya tidak mengaturnya, tetapi undang-undang pelayaran sendiri secara jelas dan terperinci menjelaskan hal yang menyangkut kecelakaan kapal termasuk tata cara pemeriksaan kecelakaan kapal.
\end{abstract}

Kata Kunci : Harmonisasi, Surat Persetujuan Berlayar, Undang-Undang Nomor 17 Tahun 2008, Undang-Undang Nomor 45 Tahun 2009.

\section{ABSTRACT}

Harmonization of regulations on competence (authority) in the Issuance Agreement Fish Sailing Ships in the Port of Belawan in terms of the Act.No. 17 of 2008 with the Act.No. 45 of 2009, particularly the provisions of Article 42 of Law. No. 45 of 2009 related to the authority of the harbor master in the issuance of the Letter of Approval Sailing, that disharmony (disharmony) legislation between Law. 17 of 2008 by Law.No. 45 of 2009, as well as including the rules below. Furthermore, the (legitimate) Letter of Approval issued by the harbor master Sailing Fishing in the port of Belawan, are legal under the law. No. 45 of 2009, but contrary to the Act. No. 12 Year 2011 on the Establishment of legislation is contrary to the principles of the law of the formation of law (the principle of legal drafting). Syahbandar legal responsibility in the fishing port was not entirely responsible for the accident because the fishing boats in the laws have not been set, but the laws of the cruise itself clearly and in detail to explain matters of ship wrecks including the inspection procedure shipwrecks.

Keywords: Harmonisation, Approval Letter Sailing, Act No. 17 of 2008, Act No. 45 of 2009.

\section{Pendahuuan}

Kapal laut merupakan alat transportasi utama sebagai pengangkut barang antar pulau karena bila dibandingkan dengan alat transportasi lainnya biayanya jauh lebih murah dan jumlah barang yang dapat diangkut jauh lebih banyak bila dibandingkan alat transportasi lainnya serta dapat menjangkau tempat yang terpencil yang tidak dapat dijangkau oleh alat transportasi lainnya. Karena pada saat ini perkembangan lingkungan Strategi Nasional dan Internasional menuntut penyelenggara pelayaran yang sesuai dengan ilmu 
pengetahuan dan teknologi, peran serta swasta dan persaingan usaha, otonomi daerah, dan akuntabilitas penyelenggara negara dengan tetap mengutamakan keselamatan dan keamanan pelayaran demi kepentingan nasional. ${ }^{1}$

Mengingat fungsi kapal laut sebagai moda transportasi (alat pengangkut) baik barang maupun penumpang maka kondisi kapal tersebut di dalam melayani jasa transportasi laut tersebut haruslah mengutamakan unsur-unsur keselamatan dan keamanan pelayaran, guna meminimalisir bahaya kecelakaan di laut yang berdampak kepada hilangnya jiwa manusia, harta benda dan terhadap pencemaran lingkungan laut.2

Kapal-kapal yang dibangun secara tradisional digunakan sebagai kapal penangkap ikan dan terhadap kapal-kapal tersebut juga dilakukan pengawasan sebagaimana dilakukan terhadap kapalkapal pengangkutan tersebut di atas, yang pengawasannya dilakukan oleh Kementerian Perhubungan, Direktorat Jenderal Perhubungan Laut, dalam hal ini dilaksanakan oleh Syahbandar, seperti pengawasan yang dilakukan oleh Syahbandar Belawan.

Selain untuk melayani pelayaran nasional maupun internasional tentunya banyak aspek yang harus diperhatikan terhadap keselamatan kapal tersebut. Sebagaimana yang diatur di dalam Undangundang Nomor 17 Tahun 2008 tentang Pelayaran yaitu aspek kelaiklautan kapal dimana kapal tersebut harus memenuhi persyaratan keselamatan kapal, pencegahan pencemaran perairan dari kapal, pengawakan, garis muat, pencemaran, kesejahteraan awak kapal dan keselamatan penumpang, status hukum kapal, manajemen keselamatan dan manajemen keamanan kapal untuk berlayar di perairan tertentu. ${ }^{3}$ Pengawasan terhadap keselamatan kapal tersebut dilakukan sejak kapal dirancang bangun, dibangun, sampai dengan

1Pasal 1 ayat 32 Undang-Undang No.17 Tahun 2008 Tentang Pelayaran

${ }^{2}$ Pasal 1 ayat 32 Undang-Undang No.17

Tahun 2008 Tentang Pelayaran

3Pasal 1 ayat (33) Undang-Undang No.17

Tahun 2008 Tentang Pelayaran kapal tidak digunakan lagi. 4 Dalam melaksanakan fungsi pengawasan tersebut dilakukan oleh pemerintah. Dalam hal ini pemerintah menunjuk pejabat yang memiliki kewenangan tertinggi untuk menjalankan dan melakukan pengawasan terhadap dipenuhinya ketentuan peraturan perundang-undangan tersebut untuk menjamin keselamatan dan keamanan pelayaran dan pejabat tersebut adalah Syahbandar. ${ }^{5}$

Syahbandar tersebut melaksanakan fungsi keselamatan dan keamanan pelayaran yang mencakup pelaksanaan, pengawasan dan penegakan hukum di bidang angkutan di perairan kepelabuhanan dan perlindungan lingkungan maritim di Pelabuhan. Hal tersebut diatur dalam Pasal 207 ayat (1) Undang-Undang Nomor 17 Tahun 2008 tentang Pelayaran.

Dalam melaksanakan pengawasan keselamatan pelayaran tersebut, dilakukan dengan cara pemeriksaan Nautis, Teknis dan Radio serta melakukan pengujian-pengujian terhadap seluruh persyaratan keselamatan kapal dalam rangka penerbitan sertifikat kapal guna terpenuhinya aspek kelaiklautan kapal, dimana kelaiklautan kapal itu sendiri adalah keadaan kapal yang memenuhi persyaratan keselamatan kapal, pencegahan pencemaran perairan dari kapal, pengawakan, garis muat, pemuatan, kesejahteraan awak kapal dan kesehatan penumpang, status hukum kapal, manajemen keselamatan kapal untuk berlayar di perairan tertentu. 6 Salah satu aspek kelaiklautan kapal tersebut adalah keselamatan kapal. Keselamatan kapal adalah keadaan kapal yang memenuhi persyaratan material, konstruksi, bangunan permesinan dan pelistrikan, stabilitas, tata susunan serta perlengkapan termasuk perlengkapan alat penolong dan radio, elektronik kapal, yang dibuktikan dengan sertifikat setelah dilakukan pemeriksaan dan

4Pasal 52 ayat (1) PP No. 51 Tahun 2002 Tentang Perkapalan

${ }^{5}$ Pasal 1 ayat (5) dan (6) PP. No. 51 Tahun 2002 tentang Perkapalan

6Pasal 1 ayat 33 UU. No. 17 Tahun 2008 tentang Pelayaran 
pengujian ${ }^{7}$ oleh Surveyor dalam hal ini dilakukan oleh Marine Inspector.

Pengawasan selanjutnya terhadap kapal dilaksanakan oleh Syahbandarsetelah terpenuhinya aspek-aspek kelaiklautan kapal dalam hal ini dituangkan dalam bentuk sertifikat-sertifikat yang ditetapkan oleh aturan-aturan nasional maupun aturanaturan internasional berupa konvensikonvensi yang telah diratifikasi oleh pemerintah Republik Indonesia, dan pengawasan selanjutnya yaitu pengawasan laik layar dimana pengawasan tersebut dilakukan oleh Syahbandar terhadap kapal yang akan berlayar meninggalkan pelabuhan untuk memastikan bahwa kapal, awak kapal dan muatannya secara teknis-administratif telah memenuhi persyaratan keselamatan dan keamanan pelayaran serta perlindungan lingkungan maritim.

Sebelum diterbitkannya Surat Persetujuan Berlayar (SPB), terlebih dahulu dilakukan pemeriksaan administratif yaitu:

a. Surat-surat dan dokumen yang dilampirkan pada saat penyerahan surat permohonan dan penerbitan Surat Persetujuan Berlayar (Port Clearance); dan

b. Sertifikat dan surat-surat kapal yang diterima oleh Syahbandar pada saat kapal tiba di pelabuhan. fisik yaitu:

Selanjutnya dilakukan pemeriksaan

a. Pemeriksaan kondisi-nautis dan radio kapal; dan

b. Pemuatan dan stabilitas kapal.

Selanjutnya pengawasan kapal-kapal tidak hanya dilakukan pada kapal-kapal laut tersebut di atas, juga dilakukan terhadap kapal penangkap ikan dalam rangka penerbitan Surat Persetujuan Berlayar (SPB) yang seharusnya dilakukan oleh Syahbandar. Pengawasan yang dilakukan dengan cara pemeriksaan fisik dan dokumen kapal ikan yang dimulai dari pemeriksaan Surat Ukur, Surat Tanda Kebangsaan Kapal, Sertifikat Keselamatan Kapal Penangkap Ikan, Surat Ijin Penangkapan Ikan (SPI) dan Ijin Usaha Perikanan (IUP) yang diterbitkan oleh Dinas Perikanan Propinsi, kemudian melakukan pemeriksaan kompetensi nakhoda/juragan

${ }^{7}$ Pasal 1 ayat (34) UU. No. 17 Tahun 2008 tentang Pelayaran kapal ikan dan kepala kamar mesin, baru diterbitkan surat persetujuan berlayar kapal ikan yang akan melaut setelah terpenuhinya ketentuan-ketentuan yang ditetapkan. Dalam hal ini Syahbandar menentukan daerah pelayaran kapal ikan sesuai dengan kondisi fisik kapal sewaktu melaksanakan survey pemeriksaan fisik kapal dalam rangka penerbitan sertifikat kelaikan dan pengawakan kapal penangkap ikan sebagaimana kapal niaga lainnya.

Dalam hal penerbitan surat persetujuan berlayar kapal ikan daerah pelayarannya ditetapkan sesuai sertifikat kelaikan dan pengawakan kapalpenangkap ikan dengan tujuan kelaut dan sejauh kompetensi ijazah nakhoda/KKM miliki, pihak Syahbandar (Syahbandar Belawan) sendiri tetap membatasi daerah pelayaran untuk menjamin keselamatan kapal, awak kapal, kerugian harta benda, jiwa dan pencemaran kapal laut.

Berdasarkan uraian diatas maka dilakukan penelitian untuk menjawab permasalahan yang dipaparkan dari latar belakang tersebut, dengan mengemukakan topik yang berjudul: "Harmonisasi Pengaturan Tentang

KewenanganDalamPenerbitan Surat Persetujuan Berlayar (SPB) Kapal Ikan Di Pelabuhan Belawan Ditinjau Dari Undang-Undang Nomor 17 Tahun 2008 Tentang PelayaranDanUndang-Undang Nomor 45 Tahun 2009 Tentang Perikanan".

\section{Perumusan Masalah}

Berdasarkan Perumusan Masalah dalam penelitian ini antara lain sebagai berikut:

1. Bagaimana harmonisasi pengaturan tentangkompetensi (kewenangan) dalam Penerbitan Surat Persetujuan Berlayar Kapal Ikan di Pelabuhan Belawan ditinjau dari UU No. 17 Tahun 2008 tentang Pelayaran dan UU. No. 45 Tahun 2009 tentang Perikanan?

2. Bagaimana dengan keabsahan (legitimasi) Surat Persetujuan Berlayar yang diterbitkan oleh Syahbandar Perikanan di Pelabuhan Belawan?

3. Bagaimana Tanggung Jawab Hukum Syahbandar di Pelabuhan 
PerikananBelawanterkait dengan Penerbitan Surat Persetujuan Berlayar Kapal Ikan?

\section{Metode Penelitian}

\section{A. Jenis dan Sifat Penelitian}

Jenis Penelitian ini adalah penelitian hukum normatif, yaitu penelitian hukum yang dilakukan dengan cara meneliti bahan pustaka atau data sekunder, ${ }^{8}$ disebut juga penelitian doktrinal, dimana hukum seringkali dikonsepkan sebagai apa yang tertulis dalam peraturan perundangundangan (law in books) atau dikonsepkan sebagai kaidah atau norma yang merupakan patokan berperilaku manusia yang dianggap pantas. ${ }^{9}$

Menurut Peter Mahmud Marzuki, penelitian hukum normatif adalah suatu proses untuk menemukan suatu aturan hukum, prinsip-prinsip hukum, maupun doktrin-doktrin hukum guna menjawab isu hukum yang dihadapi. ${ }^{10}$

Berdasarkan definisi tersebut diatas, maka jenis penelitian yang dilakukan dalam penelitian tesis ini adalah penelitian hukum normatif, karena peneliti menggunakan bahan-bahan kepustakaan sebagai data utama untuk menganalisis kasus, dan penulis tidak melakukan penelitian lapangan. Penelitian ini diteliti dengan menggunakan bahan pustaka (bahan sekunder) atau penelitian hukum perpustakaan yang secara garis besar ditujukan kepada : penelitian asas-asas hukum, penelitian terhadap sistematika hukum, penelitian terhadap sinkronisasi hukum, penelitian terhadap sejarah hukum, dan penelitian terhadap perbandingan hukum. ${ }^{11}$

\section{B. Sumber Data}

8 Soerjono Soekanto dan Sri Mamuji. Penelitian Hukum Normatif: Suatu Tinjauan Singkat. Jakarta: Raja Grafindo Persada, 2013, halaman 13.

${ }^{9}$ Amiruddin dan H Zainal Asikin.Pengantar Metode Penelitian Hukum. Jakarta: Raja Grafindo Persada, 2006, halaman 118.

10 Peter Mahmud Marzuki. Penelitian Hukum. Jakarta: Kencana Prenada Group, 2007, halaman 35.

11 Ediwarman.Monograf.Metode Penelitian Hukum (Panduan Penulisan Tesis dan Disertasi), Medan, 2011, halaman 94.
Sumber data dalam penelitian ini terdiri dari:

a. Bahan hukum primer, yaitu bahan hukum yang terdiri atas peraturan perundang-undangan. Bahan ini antara lain adalah peraturan perundang-undangan seperti Undang-undang No. 17 Tahun 2008 tentang Pelayaran beserta peraturan pelaksananya, Undang-undang No. 49 Tahun 2009 tentang Perikanan, beserta peraturan pelaksananya.

b. Bahan hukum sekunder, yaitu bahan hukum yang terdiri atas buku-buku, jurnal-jurnal hukum, pendapat para sarjana (doktrin), kasus-kasus hukum, yurisprudensi, dan hasilhasil simposium mutakhir, yang berkaitan dengan permasalahan penelitian.12

c. Bahan hukum tersier, yaitu bahanbahan hukum yang memberikan petunjuk atau penjelasan terhadap bahan hukum primer dan bahan hukum sekunder, misalnya penjelasan perundang-undangan, ensiklopedi hukum, dan indeks majalah hukum.

\section{Metode Pengumpulan Data}

Untuk memperoleh hasil yang objektif dan dapat dibuktikan kebenaran serta dapat dipertanggungjawabkan hasilnya, maka dipergunakan alat pengumpulan data sebagai berikut :

1. Studi Kepustakaan (Library Research)

Studi ini dilakukan dengan cara mengumpulkan data sekunder yang meliputi bahan hukum primer, bahan hukum sekunder, dan bahan hukum tersier. Data yang diperoleh digunakan sebagai dasar teori untuk menganalisis data primer yang diperoleh dari penelitian lapangan. Data sekunder yang berasal dari Peraturan Perundang-undangan, buku teks, data dari instansi atau lembaga lain yang memiliki keterkaitan dengan judul penelitian ini.

\section{Studi Lapangan (Field Research)}

12 Jhony Ibrahim. Teori dan Penelitian Hukum Normatif. Malang: Bayumedia Publishing, 2006, halaman 295. 


\begin{abstract}
Melakukan wawancara langsung kepada petugas (Syahbandar) yang melakukan penerbitan surat persetujuan berlayar kapal penangkap ikan di Pelabuhan Belawan.
\end{abstract}

\section{Analisis Data}

Keseluruhan data yang terdiri dari data primer dan data sekunder (bahan hukum primer, sekunder dan tersier) akan diolah dan dianalisis secara kualitatif. Penelitian kualitatif merupakan tahap penelitian yang melampaui berbagai tahapan berpikir kritis ilmiah, dimana penelitian dilakukan secara induktif, yaitu mengungkap berbagai fakta atau fenomena-fenomena yang diperoleh dari pengamatan di lapangan, lalu menganalisisnya.Selanjutnya berupaya melakukan teorisasi berdasarkan pengamatan tersebut.

\section{Hasil dan Pembahasan}

\section{A. Harmonisasi Pengaturan tentang Kompetensi (Kewenangan) dalam Penerbitan Surat Persetujuan Berlayar Kapal Ikan di Pelabuhan Belawan Ditinjau dari Undang- undang Nomor 17 Tahun 2008 tentang Pelayaran dan Undang- undang Nomor 45 Tahun 2009 tentang Perikanan}

1. Kompetensi (kewenangan) dalam Penerbitan Surat Persetujuan Berlayar Kapal Ikan di Pelabuhan Belawan ditinjau dari Undangundang Nomor 17 Tahun 2008 tentang Pelayaran

Pengawasan terhadap kapal penangkap ikan dalam rangka penerbitan surat persetujuan berlayar dahulu disebut surat ijin berlayar (SIB), Syahbandar, dalam hal ini Syahbandar di Pelabuhan Belawan, dilaksanakan dengan cara pemeriksaan fisik dan dokumen kapal ikan yang dimulai dari pemeriksaan Surat Ukur, Surat Tanda Kebangsaan Kapal, Sertifikat Keselamatan Kapal Penangkap Ikan, Surat Ijin Penangkapan Ikan (SPI) dan Ijin Usaha Perikanan (IUP) yang diterbitkan oleh Dinas Perikanan Propinsi, kemudian melakukan pemeriksaan kompetensi nakhoda/juragan kapal ikan dan kepala kamar mesin, baru diterbitkan surat persetujuan berlayar kapal ikan yang akan melaut setelah terpenuhinya ketentuanketentuan yang ditetapkan. Dalam hal keselamatan kapal ikan yang bersifat komersial, International Maritime Organization (IMO) membuat suatu aturan atau konvensi untuk keselamatan kapal penangkap ikan komersial, dikarenakan kegiatan penangkapan ikan merupakan salah satu kegiatan yang paling berbahaya dengan angka kematian yang tinggi. Menurut data yang diberikan oleh peneliti terdahulu, kecelakaan pada kapal ikan di laut merupakan jumlah terbanyak dibandingkan dengan jenis kapal lainnya. Oleh karena itu pertimbangan tersebut di atas, maka IMO memberi rekomendasi keselamatan kapal ikan komersial dengan menyelenggarakan konvensi Internasional Torremolinos tahun 1977, dengan tujuan untuk membuat aturan yang seragam bagi kapal penangkapan ikan. Konvensi Torremolinos yakni rezim keselamatan kapal penangkap ikan berukuran 24 meter atau lebih.Konvensi ini menekankan pada standar konstruksi dan perlengkapan terkait dengan keselamatan sebagaimana konvensi Safety of Life at Sea (SOLAS). Namun di Indonesia sendiri, konvensi torremolinos belum diterapkan karena bila dilihat kondisi geografis Indonesia masih termasuk daerah perairan yang berada di lintang yang rendah (wilayah tropis) yang tingkat bahayanya relatif kecil.Sedangkan untuk pengawasan kapal-kapal penangkap ikan saat ini masih menggunakan aturan Scheppen Ordonantie dan Scheppen Verordening Pasal 5 ayat (6) dan aturan Non Konvensi Bagi Kapal-Kapal Berbendera Indonesia (Non Convention Vessel Standard Indonesian Flagged atau NCVS) Pasal 45, 46, 47 dan 48.

Selanjutnya syahbandar menentukan daerah pelayaran kapal ikan sesuai dengan kondisi fisik kapal sewaktu melaksanakan survey pemeriksaan fisik kapal dalam rangka penerbitan sertifikat kelaikan dan pengawakan kapal penangkap ikan sebagaimana kapal niaga lainnya, ketentuan terhadap pengawakan kapal ikan terdiri dari Surat Keterangan 
Kecakapan (SKK) 30 mil, 60 mil dan 60 mil plus. Namun sesuai dengan Peraturan MenteriPerhubungan Nomor KM.9 tahun 2005 tentang Pendidikan dan Pelatihan, Ujian serta sertifikasi pelaut kapal penangkap ikan, surat keterangan kecakapan tersebut diubah menjadi Ahli Nautika Kapal Penangkap Ikan (ANKAPIN) dan Ahli Teknika Kapal Penangkap Ikan (ATKAPIN), khusus bagi pemegang surat keterangan kecapakan 60 mil plus dapat mengikuti updating menjadi ANKAPINIII/ATKAPIN-III. Dalam hal penerbitan surat persetujuan berlayar kapal ikan daerah pelayarannya ditetapkan sesuai sertifikat kelaikan dan pengawakan kapal penangkap ikan dengan tujuan ke laut dan sejauh kompetensi ijazah nakhoda/KKM miliki, pihak Syahbandar (Syahbandar Belawan) sendiri tetap membatasi daerah pelayaran untuk menjamin keselamatan kapal, awak kapal, kerugian harta benda, jiwa dan pencemaran kapal laut.

Dalam rangka penerbitan surat persetujuan berlayar kapal penangkap ikan (SPB) dahulu disebut Surat Izin Berlayar (SIB) yang selama ini dilaksanakan oleh Syahbandar Belawan, kemudian sejak adanya memorandum of understanding atau memorandum kesepahaman antara Direktur Jenderal Perhubungan Laut dan Direktur Jenderal Perikanan Tangkap tertanggal Jakarta, 28 Juli 2008 yang menyepakati hal-hal sebagai berikut : 1 . Syahbandar di pelabuhan Perikanan adalah Pejabat Pemerintah yang diangkat oleh Menteri Kelautan dan Perikanan yang terlebih dahulu telah mengikuti pendidikan dan pelatihan kesyahbandaran yang diselenggarakan oleh Departemen Perhubungan serta telah mendapat otoritas dari Menteri Perhubungan. 2. Pemberian Surat Persetujuan Berlayar (saat ini dikenal sebagai Surat Izin Berlayar/SIB) oleh Syahbandar di Pelabuhan Perikanan sebagai pembantu Syahbandar di Pelabuhan umum terbatas hanya dalam pemberian Surat Persetujuan Berlayar (SPB) dan tidak termasuk dalam pemeriksaan pemenuhan persyaratan kelaiklautan kapal. 3. Pelabuhan Perikanan yang lokasinya berada diluar DLKr (daerah lingkungan kerja) DLKp (daerah lingkungan kepentingan) Pelabuhan
Umum, SPB dikeluarkan oleh Syahbandar di Pelabuhan Perikanan yang telah memperoleh otoritas dari Menteri Perhubungan. 4. Pelabuhan Perikanan yang lokasinya berada di dalam DLKr / DLKp Pelabuhan Umum, Syahbandar di Pelabuhan Perikanan dapat memberikan Surat Persetujuan Berlayar sebagai pembantu Syahbandar di Pelabuhan Umum. Dalam memorandum kesepahaman tersebut para pihak sepakat untuk memberikan kewenangan untuk menerbitkan surat persetujuan berlayar yang dikenal sebagai Surat Izin Berlayar (SIB) bagi kapal penangkap ikan yang pelaksanaannya dilakukan oleh Syahbandar di pelabuhan perikanan. Akan tetapi, Syahbandar di pelabuhan perikanan dalam menerbitkan Surat Izin Berlayar kapal penangkap ikan tidak mempunyai kewenangan dalam pemeriksaan bagi pemenuhan persyaratan kelaiklautan kapal, karena pemeriksaan bagi pemenuhan persyaratan kelaiklautan kapal adalah merupakan kewenangan Departemen Perhubungan dalam hal ini Direktorat Jenderal Perhubungan Laut yang diberikan kepada Syahbandar di seluruh pelabuhan di Indonesia sebagai unit pelaksana teknis di bidang keselamatan pelayaran termasuk kapal penangkap ikan tersebut. Syahbandar di pelabuhan perikanan sendiri diangkat oleh Menteri Kelautan dan Perikanan setelah mengikuti pendidikan dan pelatihan kesyahbandaran yang diselenggarakan oleh Departemen Perhubungan serta telah mendapat otoritas dari Menteri Perhubungan.

Pemeriksaan administratif selanjutnya, Minimum safe manning certificate, yaitu dokumen keselamatan pengawakan untuk menentukan jumlah minimum awak kapal dalam rangka keselamatan pelayaran dengan masa berlaku 1 (satu) tahun yang bertujuan untuk mengetahui jumlah akomodasi/fasilitas yang ada di kapal agar cukup untuk seluruh awak kapal (Bab VIII tentang Pengawakan Pasal 188 Pemberlakuan Standar dan Petunjuk Teknis Pelaksanaan Kapal Non Konvensi Berbendera Indonesia (Non Convention Vessel Standard For Indonesian Flagged), sedangkan untuk kapal-kapal yang berlayar 
ke luar negeri Safe Manning Certificate mengacu kepada STCW 78/95, dalam hal ini penerbitan sertifikatnya sesuai dengan Keputusan Menteri No. KM. 70 Tahun 1998 tentang Pengawakan Kapal Niaga.

Daftar Anak Buah Kapal (ABK) atau Crew List, gunanya untuk mengetahui secara pasti jumlah awak kapal yang ikut berlayar nama dan jabatan awak kapal tersebut. Sertifikat keselamatan kapal terdiri dari sertifikat keselamatan konstruksi kapal barang, sertifikat keselamatan perlengkapan kapal barang, sertifikat keselamatan radio kapal barang, untuk memastikan bahwa seluruh sertifikat kapal masih berlaku (valid), yang dilampirkan pada saat penyerahan surat permohonan penerbitan Surat Persetujuan Berlayar (Port Clearance).

Kemudian pemeriksaan fisik di atas kapal, walaupun telah diterbitkannya seluruh sertifikat keselamatan kapal dan masih berlaku namun sebagai bentuk pengawasan yang melekat terhadap kelaiklautan kapal dan terhadap kelaiklayaran suatu kapal, maka tetap juga dilaksanakan pemeriksaan-pemeriksaan fisik yang berulang terhadap kapal tersebut.Pemeriksaan fisik diatas kapal dilakukan oleh pejabat pemeriksa kelaiklautan kapal terhadap kondisi nautisteknis dan radio kapal, serta pemuatan dan stabilitas kapal. ${ }^{33}$ Pemeriksaan fisik kapal dalam rangka penerbitan surat persetujuan berlayar (port clearance) dilakukan antara lain dengan memeriksa peralatan navigasi, peralatan radio komunikasi, alat-alat keselamatan, alat-alat pemadam kebakaran, permesinan dan pelistrikan, oily water separator, pengawakannya dan masih banyak lagi pemeriksaan fisik kapal lainnya.

Demikian secara keseluruhan bentuk pengawasan keselamatan pelayaran yang dilakukan oleh Direktorat Jenderal Perhubungan Laut dalam hal ini dilaksanakan oleh Syahbandar sebagaimana yang diamanatkan oleh UU No. 17 Tahun 2008 tentang Pelayaran.

13 Peraturan Menteri Perhubungan No.KM.01 Tahun 2010 tentang Tata Cara Penerbitan Surat Persetujuan Berlayar Pasal 4 dan 5.

\section{Kompetensi (kewenangan) dalam Penerbitan Surat Persetujuan Berlayar Kapal Ikan di Pelabuhan Belawan ditinjau dari Undang Undang Nomor 45 Tahun 2009 tentang perubahan atas Undang Undang Nomor 31 tahun 2004 tentang Perikanan}

Setelah dilakukan penelitian, pada awalnya pemberian Surat Izin Berlayar (SIB) kapal perikanan dapat diterbitkan oleh syahbandar dari Direktorat Jenderal Perhubungan Laut setelah melalui beberapa proses persyaratan yang dikeluarkan oleh Departemen Kelautan dan Perikanan dalam hal ini Direktorat Jenderal Perikanan Tangkap yang didelegasikan kepada Kantor Pelabuhan Perikanan di Indonesia untuk menerbitkan Lembar Laik Operasional (LLO) sebelum kapal ikan berlayar dengan surat Departemen Kelautan dan Perikanan, Direktur Jenderal Pengendalian Sumber Daya Kelautan dan Perikanan Nomor : 125/PSDKP/1.4/V/2003 tertanggal Jakarta, 12 Mei 2003 perihal Pemberian SIB kapal perikanan yang ditujukan kepada Direktur Jenderal Perhubungan Laut yang isinya meminta agar bersinergi dalam pelaksanaan tugas dan tanggung jawab serta tidak terjadi kesimpangsiuran pelaksanaan di lapangan yang dapat mempengaruhi keberangkatan kapal-kapal ikan untuk melakukan operasinya, maka diharapkan bantuannya untuk menyampaikan kepada para syahbandar di tiap pelabuhan yang digunakan juga sebagai Pelabuhan Pangkalan/kegiatan kapal perikanan untuk memberikan SIB bagi kapal perikanan setelah terlebih dahulu ada Lembar Laik Operasional (LLO) sekarang Surat Laik Operasi yang dikeluarkan oleh Pengawas Perikanan.

Selanjutnya dari perihal surat tersebut di atas, oleh Departemen Kelautan dan Perikanan, Direktorat Jenderal Pengawasan Sumber Daya Kelautan dan Perikanan mengeluarkan surat yang ditujukan kepada Pelabuhan Perikanan Samudera Belawan dan Pelabuhan Perikanan Nusantara Sibolga dengan surat Nomor : 752/PSDKP.1.4/PD.140/IX/2004 tertanggal Jakarta, 3 September 2004 perihal Aktivitas Petugas Pengawas, yang isinya agar 
Kepala Pelabuhan Perikanan Samudera Belawan dan Kepala Pelabuhan Perikanan Nusantara Sibolga, berkoordinasi dengan ADPEL/Syahbandar agar Surat Izin Berlayar Kapal Perikanan tidak diterbitkan sebelum kapal mendapatkan Lembar laik operasional (LLO) dari Pengawas Perikanan. Kapal Perikanan yang SIB keluar tanpa LLO agar dilaporkan ke Ditjen PSDKP untuk dikoordinasikan dengan Ditjen Perhubungan Laut.

Dari kedua surat yang dikeluarkan oleh Departemen Kelautan dan Perikanan tersebut di atas, maka dapat dijelaskan bahwa sebenarnya kewenangan dalam penerbitan SIB kapal perikanan adalah wewenang dari Adpel/Syahbandar Direktorat Jenderal Perhubungan Laut, dan hal tersebut merupakan sinergitas antara instansi terkait sebagaimana yang dilakukan dalam penerbitan Surat Izin Berlayar kapalkapal niaga terhadap instansi-instansi seperti Bea dan Cukai (Customs), Karantina (Quarantine), Imigrasi (Imigration), Kesehatan Pelabuhan (Health Quarantine), dimana instansi-instansi tersebut mengeluarkan surat persetujuan (clearance). Setelah diterbitkan surat persetujuan dari instansi-instansi terkait tersebut, diterbitkanlah SIB kapal niaga untuk dapat berlayar dari pelabuhan asal ke pelabuhan tujuan yang lazim disebut dengan Port Clearance.

Namun dalam perjalanannya, pemberian SIB kapal perikanan mengalami dinamika (pergeseran) sejak adanya Memorandum Kesepahaman (Memorandum of Understanding) tertanggal Jakarta 28 Juli 2008 antara Direktur Jenderal Perhubungan Laut Departemen Perhubungan dengan Direktur Jenderal Perikanan Tangkap Departemen Kelautan dan Perikanan, dengan berdasarkan pertimbangan-pertimbangan sebagai berikut:

1. Undang-undang Nomor 31 Tahun 2004 tentang Perikanan

2. Undang-undang Nomor 17 Tahun 2008 tentang Pelayaran

3. Hasil pembahasan antara Sekretaris Jenderal Departemen Kelautan dan Perikanan bersama Direktur Jenderal Perikanan Tangkap Departemen Kelautan dan Perikanan dan Sekretaris Jenderal Departemen
Perhubungan bersama Direktur Jenderal Perhubungan Laut Departemen Perhubungan yang diselenggarakan di Ruang Rapat Kutai lantai 7 Gedung Karsa Departemen Perhubungan, Jl. Medan Merdeka Barat Nomor 8, Jakarta Pusat pada tanggal 28 Juli 2008.

Dari pertimbangan-pertimbangan tersebut, telah menyepakati hal-hal sebagai berikut:

1) Syahbandar di Pelabuhan Perikanan adalah Pejabat Pemerintah yang diangkat oleh Menteri Kelautan dan Perikanan yang terlebih dahulu telah mengikuti pendidikan dan pelatihan kesyahbandaran yang diselenggarakan oleh Departemen Perhubungan serta telah mendapat otoritas dari Menteri Perhubungan.

2) Pemberian Surat Persetujuan Berlayar (saat ini dikenal sebagai Surat Izin Berlayar/SIB) oleh Syahbandar di Pelabuhan Perikanan sebagai pembantu Syahbandar di Pelabuhan Umum terbatas hanya dalam pemberian Surat Persetujuan Berlayar (SPB) dan tidak termasuk dalam pemeriksaan pemenuhan persyaratan kelaiklautan kapal.

3) Pelabuhan Perikanan yang lokasinya berada diluar DLKr/DLKp Pelabuhan Umum, SPB dikeluarkan oleh Syahbandar di Pelabuhan Perikanan yang telah memperoleh otoritas dari Menteri Perhubungan.

4) Pelabuhan Perikanan yang lokasinya berada didalam DLKr/DLKp Pelabuhan Umum, Syahbandar di Pelabuhan Perikanan dapat memberikan Surat Persetujuan Berlayar sebagai pembantu Syahbandar di Pelabuhan Umum.

Berdasarkan penjelasan dari memorandum kesepahaman tersebut di atas, sebutan "Syahbandar di Pelabuhan Perikanan" baru muncul setelah diterbitkannya Undang-undang No. 31 Tahun 2004 tentang Perikanan. Padahal sebutan "Syahbandar" sendiri dikenal sejak zaman kolonial Belanda adalah Syahbandar yang dijelaskan dalam Pasal 1 ayat (1) Peraturan Bandar Tahun 1925, kemudian sebutan Syahbandar dijelaskan dalam 
Scheepen Ordonantie (SO) dan Scheepen Verordening (SV) tahun 1935 yang diterjemahkan ke dalam bahasa Indonesia menjadi peraturan pengawasan kapal-kapal tahun 1935, menyebutkan istilah Syahbandar dalam Pasal 3 Peraturanperaturan Keselamatan Pelayaran, bahwa Syahbandar-syahbandar ahli adalah pengawas-pengawas keselamatan kapalkapal di tempat kedudukannya.

Syahbandar sendiri dalam melaksanakan pengawasan keselamatan pelayarannya melakukan pemeriksaan dan pengujian terhadap kapal dalam rangka menerbitkan sertifikat kesempurnaan dan sertifikat keselamatan, dimana setiap kapal yang berlayar ke perairan luar, harus dilengkapi dengan sertifikat kesempurnaan yang berlaku yang diberikan oleh atau atas nama Direktur Jenderal Perhubungan Laut dalam hal ini adalah Syahbandar. Kemudian setelah Negara Indonesia merdeka dengan kurun waktu yang begitu lama, akhirnya pengawasan keselamatan pelayaran ini diatur secara khusus dalam Undang-undang Nomor 21 Tahun 1992 tentang Pelayaran Pasal 40 yang berbunyi: "Setiap kapal yang memasuki pelabuhan dan selama berada di pelabuhan wajib mematuhi peraturanperaturan untuk menjaga ketertiban dan kelancaran lalu lintas kapal di pelabuhan, yang pengawasannya dilakukan oleh Syahbandar", kemudian terakhir diubah dengan Undang-undang Nomor 17 Tahun 2008 tentang Pelayaran.

Selanjutnya dalam memorandum kesepahaman yang telah disebutkan di atas, pada butir 2 bahwa pemberian SPB oleh Syahbandar di Pelabuhan Perikanan sebagai pembantu Syahbandar di Pelabuhan Umum terbatas hanya dalam pemberian Surat Persetujuan Berlayar dan tidak termasuk dalam pemeriksaan pemenuhan persyaratan kelaiklautan kapal (nautis dan teknis). Tetapi di dalam pelaksanaan operasionalnya dilakukan sesuai dengan Peraturan Menteri Kelautan dan Perikanan Nomor 3/PERMENKP/2013 tentang Kesyahbandaran di Pelabuhan Perikanan Pasal 5 huruf $\mathrm{f}$ dan $g$ yang menjelaskan bahwa Syahbandar di pelabuhan perikanan mempunyai tugas dan wewenang menerbitkan Surat Persetujuan Berlayar, dan memeriksa teknis dan nautis kapal perikanan dan memeriksa alat penangkapan ikan, dan alat bantu penangkapan ikan. Dari memorandum kesepahaman antara Dirjen Perhubungan Laut Departemen Perhubungan dengan Dirjen Perikanan Tangkap Departemen Kelautan dan Perikanan, dan peraturan menteri kelautan dan perikanan tersebut bertolak belakang satu sama lainnya, bahwa yang tersebut di dalam memorandum tidak sesuai dengan yang tersebut di dalam peraturan menteri kelautan dan perikanan.

Berdasarkan uraian tersebut di atas, bahwa yang terdapat dalam memorandum kesepahaman terkait dengan pemeriksaan kelaiklautan kapal (nautis dan teknis) adalah bagian dari tugas dan wewenang dari Syahbandar di Pelabuhan Umum Direktorat Jenderal Perhubungan Laut, tetapi yang terdapat dalam peraturan menteri perikanan tersebut adalah menjadi bagian dari tugas dan wewenang Syahbandar di Pelabuhan Perikanan Direktorat Jenderal Perikanan Tangkap. Hal tersebut sangatlah bertentangan dalam sistem hukum di Indonesia, karena undang-undang perikanan seharusnya mengatur perihal hanya sebatas perikanan saja, tidak mengatur tentang keselamatan pelayaran sebagaimana yang diatur dalam undang-undang pelayaran.

Sebagaimana telah dikemukakan tersebut di atas dalam rangka penerbitan Surat Persetujuan Berlayar kapal pada umumnya yang diterbitkan oleh Syahbandar Direktorat Jenderal Perhubungan Laut yang seharusnya ada persetujuan-persetujuan (clearance) dari instansi-instansi terkait. Demikian juga seharusnya terhadap kapal perikanan, bahwa setelah diterbitkan Surat Laik Operasi (SLO) dan dokumen lainnya yang berkaitan dengan perikanan (clearance) dari Pelabuhan Perikanan Samudera, selanjutnya diterbitkan Surat Persetujuan Berlayar (SPB) kapal ikan dari Syahbandar di Pelabuhan Umum. Namun kenyataannya sampai saat ini penerbitan SPB kapal ikan dilaksanakan oleh Syahbandar di Pelabuhan Perikanan. Undang-undang Nomor 45 Tahun 2009 tentang Perubahan atas Undangundang Nomor 31 Tahun 2004 tentang Perikanan secara keseluruhan dari isi undang-undang tersebut berisikan tentang perubahan meliputi penegakan hukum dibidang perikanan, masalah pengelolaan 
perikanan, antara lain kepelabuhanan perikanan, konservasi, dan kesyahbandaran dan perluasan yurisdiksi pengadilan perikanan. Sedangkan

perubahan kesyahbandaran pada Undang-undang Nomor 45 Tahun 2009 tentang Perubahan Atas Undang-undang Nomor 31 Tahun 2004 tentang Perikanan sebenarnya pada Kesyahbandaran tersebut merupakan hasil adopsi dari tugas dan wewenang syahbandar yang ada pada Undang-undang Nomor 17 Tahun 2008 tentang Pelayaran. Sementara itu,Pasal 42 ayat (1) Undang-undang Nomor 31 Tahun 2004 tentang Perikanan menjelaskan bahwa dalam rangka keselamatan pelayaran, ditunjuk syahbandar di pelabuhan perikanan, dan pada Pasal 42 ayat (4) dari undang-undang tersebut menyebutkan bahwa Syahbandar di pelabuhan perikanan sebagaimana dimaksud pada ayat (1) diangkat oleh Menteri (Menteri Kelautan dan Perikanan Republik Indonesia). Berbeda dengan ketentuan yang dimaksud dalam Pasal 42 ayat (1) dari Undang-undang No. 45 Tahun 2009 tentang Perikanan yang menyebutkan bahwa dalam rangka keselamatan operasional kapal perikanan, ditunjuk syahbandar di pelabuhan perikanan yang diangkat oleh Menteri yang membidangi urusan pelayaran (Pasal 42 ayat 4).

Dari ketentuan Pasal 42 ayat (1) Undang-undang No. 45 Tahun 2009 tersebut di atas, dapat dijelaskan bahwa syahbandar di pelabuhan perikanan tidak mengemban tugas dalam rangka keselamatan pelayaran, tetapi hanya dalam rangka keselamatan operasional kapal perikanan saja. Selanjutnya dapat diketahui bahwa esensi dari undang-undang tersebut tidak ada mengatur tentang keselamatan pelayaran kapal ikan, tetapi pada Peraturan Menteri Kelautan dan Perikanan Nomor: 3/PERMENKP/2013 tanggal 21 Februari 2013 Pasal 1 angka 6 ada mengatur tentang Keselamatan Pelayaran yang diterangkan dengan defenisi: Keselamatan Pelayaran yaitu rangkaian tindakan pemeriksaan terhadap kelaiklautan kapal, laik tangkap dan laik simpan yang dinyatakan dengan dokumen kapal. Meneliti serta mencermati antara UndangUndang Nomor 45 Tahun 2009 tersebut dengan Peraturan Menterinya bertentangan dengan azas hokum lex superior derogate legi inferior.

$\begin{array}{ccr}\text { Dengan } & \text { demikian terjadi } \\ \text { ketidakharmonisan } & \text { (disharmonisasi) }\end{array}$
peraturan perundang-undangan antara UU No. 17 Tahun 2008 dengan UU No. 45 Tahun 2009, serta termasuk peraturan dibawahnya seperti Peraturan Menteri Perhubungan Nomor : PM. 82 Tahun 2014 yang merupakan pengganti dari Peraturan Menteri Perhubungan Nomor : KM. 01 Tahun 2010 dan Peraturan Menteri Perhubungan Nomor : PM. 23 Tahun 2014 tentang Perubahan atas Peraturan Menteri Perhubungan Nomor : KM. 01 Tahun 2010 Tentang Tata Cara Penerbitan Surat Persetujuan Berlayar (Port Clearance) terhadap UU No. 17 Tahun 2008 dimana pada Peraturan Menteri No. PM. 82 Tahun 2014 Pasal 2 ayat (3) terjadi pertentangan dengan perintah Undang-undang di dalam Pasal 207 ayat(1), dan juga di dalam konsideran Peraturan Menteri Perhubungan No. PM. 82 Tahun 2014 tersebut juga memasukkan Undang-undang Nomor 45 tahun 2009 tentang Perikanan sebagai salah satu unsur penerbitan Permenhub No. PM. 82 Tahun 2014 tersebut. Selanjutnya Peraturan Menteri Kelautan dan Perikanan terhadap UU No. 45 Tahun 2009 juga saling bertentangan.Sebab esensi dari UU No. 45 Tahun 2009 seharusnya hanya mengatur tentang perikanan saja yang di dalamnya tidak mengatur tentang keselamatan pelayaran kapal perikanan, sedangkan esensi dari UU No. 17 Tahun 2008 secara jelas telah mengatur tentang keselamatan pelayaran, namun dari segi sinergitas antara Permenhub No. PM. 82 Tahun 2014 dengan Permen Kelautan dan Perikanan No. 3/PERMEN-KP/2013, terjadi sinergitas.

Dengan semakin jelasnya perbedaan antara undang-undang perikanan dengan peraturan menterinya tentang kesyahbandaran menunjukkan bahwa semakin jelas maksud dan tujuan dari Kementerian Kelautan dan Perikanan, untuk mengambil alih tugas dan wewenang dari Syahbandar di Direktorat Jenderal Perhubungan Laut. Hal tersebut sangat tampak apabila dilihat dari Lampiran V Peraturan Menteri No. 3 /PERMEN-KP/2013 dalam bentuk format tentang Surat Pernyataan Kesiapan Kapal Berangkat dari 
nakhoda (master sailing declaration), sebagai dasar hukumnya adalah Ordonansi kapalkapal tahun 1935 dan Lampiran VIII dalam bentuk format tentang Hasil Pemeriksaan Teknis dan Nautis Kapal Perikanan, Alat Penangkapan Ikan, dan Alat Bantu Penangkapan Ikan yang isinya menguraikan tentang pemeriksaan yang harus dilakukan oleh Syahbandar di Pelabuhan Perikanan yaitu terkait pemeriksaan Nautis, Teknis dan Radio antara lain: memeriksa Peralatan Navigasi, Peralatan Radio Komunikasi, Alatalat Keselamatan, Alat-alat Pemadam Kebakaran, Pintu pintu dan bukaan-bukaan, Permesinan dan Perlistrikan Kapal Perikanan,dan Peralatan Pencegahan Pencemaran. Selain itu pemeriksaan dilakukan terhadap Pengawakan antara lain: Nakhoda, Jumlah Perwira dan Jumlah ABK (anak buah kapal), dan melakukan pemeriksaan terhadap Alat Penangkapan Ikan.

Berdasarkan hasil wawancara yang dilakukan dengan saudara JATMOKO, A. Pi., Jabatan Kepala Seksi Kesyahbandaran Perikanan/Syahbandar Perikanan Pelabuhan Perikanan Samudera Belawan pada hari Kamis tanggal 17 Desember 2015, bahwa dari beberapa pertanyaan yang diajukan kepadanya, beliau memberikan keterangan antara lain: Syahbandar di Pelabuhan Perikanan dalam rangka keselamatan pelayaran kapal ikan melakukan rangkaian pemeriksaan seperti memeriksa semua dokumen kapal, memeriksa kelaiklautan kapal dan aspek keselamatan yaitu bangunan (body) kapal, mesin kapal, alat-alat keselamatan kapal, dan memeriksa alat tangkap apakah sudah sesuai dengan dokumen alat tangkap kapal tersebut. Kemudian dari keterangan tersebut ditanyakan apa yang menjadi dasar hukum dilakukannya pemeriksaan tersebut, beliau memberi jawaban, bahwa yang menjadi dasar hukum pemeriksaan adalah Peraturan Menteri Kelautan dan Perikanan Nomor 3 /PERMEN-KP/2013, kemudian beliau menambahkan bahwa setiap kapal pengangkut ikan harus memiliki SIKPI (Surat Izin Kapal Pengangkut Ikan) dan kapal kargo (barang) yang mempunyai SIKPI harus mempunyai Surat Laik Operasi (SLO).

Dari penjelasan yang telah diuraikan seluruhnya di atas, terlihat bahwa
Kementerian Kelautan dan Perikanan telah membuat dikotomi terhadap istilah syahbandar di pelabuhan umum dengan syahbandar di pelabuhan perikanan, demikian juga terhadap istilah kapal itu sendiri.

\section{B. Keabsahan (Legitimasi) Surat Persetujuan Berlayar yang diterbitkan oleh Syahbandar Perikanan di Pelabuhan Belawan}

\section{Keabsahan Surat Persetujuan Berlayar yang diterbitkan oleh Syahbandar Belawan ditinjau dari Undang-Undang Nomor 17 Tahun 2008 tentang Pelayaran}

Dalam rangka penerbitan Surat Persetujuan Berlayar (Port Clearance) yang diatur dalam Peraturan Menteri Perhubungan Nomor : KM. 01 Tahun 2010 tentang Tata Cara Penerbitan Surat Persetujuan Berlayar (Port Clearance) yang menerangkan bahwa Penerbitan Surat Persetujuan Berlayar (Port Clearance) adalah suatu proses pengawasan yang dilakukan oleh Syahbandar terhadap kapal yang akan berlayar meninggalkan pelabuhan untuk memastikan bahwa kapal, awak kapal dan muatannya secara teknis-administratif telah memenuhi persyaratan keselamatan dan keamanan pelayaran serta perlindungan lingkungan maritim. Dalam pelaksanaan penerbitan Surat Persetujuan Berlayar yang dilakukan oleh syahbandar, terlebih dahulu dilakukan pemeriksaan administratif dan fisik di atas kapal.

Pemeriksaan administratif berupa pemeriksaan surat-surat dan dokumen kapal sesuai dengan Lampiran III Peraturan Menteri Perhubungan Nomor : KM 01 Tahun 2010 tersebut di atas. Sebelum dilakukan pemeriksaan administratif, nakhoda kapal membuat surat pernyataan tentang keberangkatan kapal (master sailing declaration) dengan format sesuai Lampiran II dari Peraturan Menteri Perhubungan Nomor : KM 01 Tahun 2010. Setelah pemeriksaan administratif dipenuhi, maka dilakukan pemeriksaan fisik terhadap kapal yang akan berlayar.

Setelah dilakukan pemeriksaan administratif dan fisik, maka diterbitkan 
Surat Persetujuan Berlayar (Port Clearance) oleh Syahbandar dan Surat Persetujuan Berlayar yang diterbitkan oleh Syahbandar Direktorat Jenderal Perhubungan Laut inilah sah (legitimate) sesuai dengan undangundang yang berlaku. Sehingga bila dilakukan penelitian dan penganalisaan antara Peraturan Menteri Perhubungan Nomor KM.01 Tahun 2010 tentang Tata Cara Penerbitan Surat Persetujuan Berlayar (Port Clearance) dengan Peraturan Menteri Kelautan dan Perikanan Nomor : 3/PERMEN-KP/2013 tentang Kesyahbandaran di Pelabuhan Perikanan juga terdapat hal-hal atau pengaturanpengaturan yang serba ganda tentang pengawasan terhadap kapal perikanan.

Apabila dilihat dari seluruh peraturan perundang-undangan yang ada berdasarkan dari teori pembentukan undang-undang, mulai dari legal drafting, azas-azas hukum tata Negara, azas hukum lex specialist derogate legi generali, teori kewenangan serta teori harmonisasi seluruhnya bertentangan dengan asas-asas pembentukan undang-undang, dimana terjadinya ketidakharmonisan (disharmonisasi) hukum antara undangundang yang mengatur tentang pelayaran dengan undang-undang yang mengatur tentang perikanan. Karena hal tersebut berkaitan dengan keabsahan (legitimasi) dalam penerbitan Surat Persetujuan Berlayar (SPB) kapal ikan, bahwa aturan hukum mana yang seharusnya digunakan dan seharusnya mendapatkan prioritas sebagaimana ada 2 (dua) aturan hukum lex specialist (hukum khusus) yang sama mengatur tentang kapal. Karena keduaduanya merupakan aturan hukum khusus yaitu Undang-undang Nomor 17 Tahun 2008 tentang Pelayaran khusus mengatur tentang Keselamatan Pelayaran dan Undang-undang Nomor 45 Tahun 2009 tentang Perubahan Atas Undang-undang Nomor 31 Tahun 2004 tentang Perikanan khusus mengatur tentang Perikanan.

2. Keabsahan Surat Persetujuan Berlayar yang Diterbitkan oleh Syahbandar Perikanan di Pelabuhan Belawan Ditinjau dari Undang-undang Nomor 45 Tahun 2009 tentang Perikanan
Penerbitan Surat Persetujuan Berlayar Kapal Ikan yang dikeluarkan oleh Syahbandar di Pelabuhan Perikanan berkaitan dengan keselamatan berlayar kapal ikan sebenarnya sudah bertentangan dengan Undang-undang Nomor 45 Tahun 2009 tentang Perubahan Atas Undangundang Nomor 31 Tahun 2004 tentang Perikanan itu sendiri, karena undangundang tersebut hanya mengatur tentang keselamatan operasional kapal ikan. Sementara Undang-undang Nomor 31 Tahun 2004 tentang Perikanan mengatur tentang keselamatan pelayaran dan membuat istilah baru yaitu "Syahbandar di Pelabuhan Perikanan " serta mendikotomikannya dengan "Syahbandar" dari Direktorat Jenderal Perhubungan Laut dan istilah tersebut yang seolah-olah murni adalah merupakan bagian hukum dari undangundang tentang perikanan tersebut. Dengan adanya istilah tersebut, maka Syahbandar di Pelabuhan Perikanan Kementerian Kelautan dan Perikanan dengan demikian mempunyai kewenangan untuk mengambil alih dalam penerbitan Surat Persetujuan Berlayar (SPB) tersebut dari Syahbandar Direktorat Jenderal Perhubungan Laut, dimana pada awalnya Syahbandar Direktorat Jenderal Perhubungan Laut memberikan pelayanan penerbitan Surat Persetujuan Berlayar (SPB) berada di Kantor Syahbandar Administrator Pelabuhan Utama Belawan, namun setelah diundangkannya Undang-Undang Nomor 31 Tahun 2004 tentang Perikanan tersebut Kementerian Kelautan dan Perikanan, Pelabuhan Perikanan Samudera Belawan membuat sistem pelayanan satu atap (samsat) kelautan di Pelabuhan Perikanan Samudera Belawan, yang anggotanya antara lain: Dinas Kelautan dan Perikanan Propinsi Sumatera Utara, Dinas Perikanan dan Kelautan Kota Medan, Direktorat Polisi Air (Ditpolair) Belawan, Syahbandar Adpel Utama Belawan dan PSDKP Belawan. Namun, setelah samsat kelautan tersebut berjalan, pada tanggal 31 Januari 2007 dengan suratnya Nomor : 16.2/PPSB./PL.220/1/2007, Kepala Pelabuhan Perikanan Samudera Belawan memberitahukan agar mengosongkan Gedung Samsat Kelautan pada Maret 2007, kemudian dengan suratnya Nomor: 34.1/PPSB.C/KP.440/III/2007, tertanggal 
Belawan, 7 Maret 2007, bahwa pada tanggal 10 Maret 2007 Pelabuhan Perikanan Samudera Belawan mulai mengoperasikan Syahbandar di Pelabuhan Perikanan Samudera Belawan dan dilanjutkan dengan suratnya Nomor : 451/PPSB.C/PI420/III/2007 perihal Pengurusan Surat Izin Berlayar (SIB) Bagi Kapal Perikanan di Pelabuhan Perikanan Samudera Belawan tanggal 30 Maret 2007 yang ditujukan kepada Pengusaha kapal perikanan/pengurus kapal perikanan Belawan agar membuat SIB (Surat Izin Berlayar) yang diterbitkan oleh Syahbandar yang diangkat oleh Menteri Kelautan dan Perikanan, karena pemberian SIB oleh Syahbandar Perikananlah yang sah menurut hukum.

\section{Tanggung Jawab Hukum Syahbandar di Pelabuhan Perikanan Belawan Terkait dengan Penerbitan Surat Persetujuan Berlayar Kapal Ikan}

Pengawasan yang dilakukan oleh Syahbandar Direktorat Jenderal Perhubungan Laut apabila terjadi kecelakaan terhadap awak kapal maka dilakukan tindakan-tindakan hukum berkaitan dengan hak dan kewajiban awak kapal sebagaimana yang diatur di dalam Peraturan Pemerintah Nomor 7 Tahun 2000 tentang Kepelautan. Apabila kecelakaan kapal tersebut mengakibatkan cedera permanen yang mengakibatkan awak kapal tidak dapat beraktifitas secara normal, menyebabkan kematian dan lain-lain, diatur dalam Pasal 28 sampai dengan Pasal 31 PP. No. 7 Tahun 2000 tentang Kepelautan.

Sebagaimana ketentuan Pasal 28 menyebutkan:

(1) Pengusaha angkutan di perairan wajib menanggung biaya perawatan dan pengobatan bagi awak kapal yang sakit atau cidera selama berada di atas kapal.

(2) Awak kapal yang sakit atau cedera akibat kecelakaan sehingga tidak dapat bekerja atau harus dirawat, pengusaha angkutan di perairan selain wajib mempunyai perawatan dan pengobatan juga wajib membayar gaji penuh jika awak kapal tetap berada atau dirawat di kapal
(3) Jika awak kapal sebagaimana dimaksud dalam ayat (2) harus diturunkan dari kapal untuk perawatan di darat, pengusaha angkutan di perairan selain wajib membiayai perawatan dan pengobatan, juga wajib membayar $100 \%$ dari gaji minimumnya setiap bulan pada bulan pertama, dan sebesar $80 \%$ dari gaji minimumnya setiap bulan berikutnya, sampai yang bersangkutan sembuh sesuai surat keterangan petugas medis, dengan ketentuan tidak lebih dari 6 (enam) bulan untuk yang sakit dan tidak lebih dari 12 (dua belas) bulan untuk yang cedera akibat kecelakaan.

(4) Bila awak kapal diturunkan dan dirawat di luar negeri, selain biaya perawatan dan pengobatan, pengusaha angkutan di perairan juga menanggung biaya pemulangan kembali ke tempat domisilinya.

Selanjutnya ketentuan Pasal 29 PP.

No. 7 Tahun 2000 menyebutkan: Besarnya ganti rugi atas kehilangan barang-barang milik awak kapal akibat tenggelam atau terbakarnya kapal, sesuai dengan nilai barang-barang yang wajar dimilikinya yang hilang atau terbakar.

Ketentuan Pasal 30 berbunyi:

(1) Jika awak kapal setelah dirawat akibat kecelakaan kerja, menderita cacat tetap yang mempengaruhi kemampuan kerja, besarnya santunan ditentukan

a. Cacat tetap yang mengakibatkan kemampuan kerja hilang 100\% besarnya santunan minimal Rp. 150.000.000,- (seratus lima puluh juta rupiah);

b. Cacat tetap yang mengakibatkan kemampuan kerja berkurang, besarnya santunan ditetapkan sebesar persentase dari jumlah sebagaimana ditetapkan dalam huruf a, sebagai berikut :

1) Kehilangan satu lengan : $40 \%$

2) Kehilangan kedua lengan : $100 \%$

3) Kehilangan satu telapak tangan: $30 \%$ 
4) Kehilangan kedua telapak tangan: $80 \%$

5) Kehilangan satu kaki dari paha: $40 \%$

6) Kehilangan kedua kaki dari paha: $100 \%$

7) Kehilangan satu telapak kaki: $30 \%$

8) Kehilangan kedua telapak kaki: $80 \%$

9) Kehilangan satu mata: $30 \%$

10) Kehilangan kedua mata: $100 \%$

11) Kehilangan pendengaran satu telinga: $15 \%$

12) Kehilangan pendengaran kedua telinga: $40 \%$

13) Kehilangan satu jari tangan: $10 \%$

14) Kehilangan satu jari kaki: $5 \%$

(2) Jika awak kapal kehilangan beberapa anggota badan sekaligus sebagaimana dimaksud dalam ayat (1) huruf b, besarnya santunan ditentukan dengan menjumlahkan besarnya persentase, dengan ketentuan tidak melebihi jumlah sebagaimana ditetapkan dalam ayat (1) huruf a.

Ketentuan Pasal 31 berbunyi:

(1) Jika awak kapal meninggal dunia di atas kapal, pengusaha angkutan di perairan wajib menanggung biaya pemulangan dan penguburan jenazahnya ke tempat yang dikehendaki oleh keluarga yang bersangkutan sepanjang keadaan memungkinkan.

(2) Jika awak kapal meninggal dunia, pengusaha angkutan di perairan wajib membayar santunan :

a. Untuk meninggal karena sakit besarnya santunan minimal Rp. 100.000.000,- (seratus juta rupiah);

b. Untuk meninggal akibat kecelakaan kerja besarnya santunan minimal Rp. 150.000.000,- $\quad$ (seratus lima puluh juta).

(3) Santunan sebagaimana dimaksud dalam ayat (2), diberikan kepada ahli warisnya sesuai dengan ketentuan yang berlaku.

Selanjutnya apabila terjadi kerusakan pada muatan kapal baik yang diakibatkan oleh kondisi alam fforce majeure) ataupun diakibatkan oleh kondisi teknis didalam kapal itu sendiri, maka nakhoda kapal akan membuat laporan berupa sea note of protes (laporan kondisi muatan kapal) yang diketahui oleh Syahbandar untuk disampaikan kepada pihak asuransi sebagaimana yang dimaksud dalam Pasal 41 ayat (3) UU No. 17 Tahun 2008 tentang Pelayaran, bahwa: "Perusahaan angkutan di perairan wajib mengasuransikan tanggung jawabnya sebagaimana dimaksud pada ayat (1) dan melaksanakan asuransi perlindungan dasar penumpang umum sesuai dengan ketentuan peraturan perundang-undangan".

Sedangkan untuk kapal itu sendiri, apabila terjadi kecelakaan kapal yang mengalami tenggelam, terbakar, tubrukan, kecelakaan yang menyebabkan terancamnya jiwa manusia dan kerugian harta benda, serta kapal kandas, maka dilakukan pemeriksaan, yaitu dengan membuat Berita Acara Pemeriksaan Pendahuluan berkaitan dengan kecelakaan tersebut terhadap awak kapal yang mengalami kecelakaan tersebut sesuai dengan PP No.1 Tahun 1998 tentang Pemeriksaan Kecelakaan Kapal dan Peraturan Menteri Perhubungan Nomor KM. 55 Tahun 2006 tentang Tata Cara Pemeriksaan Kecelakaan kapal. Pemeriksaan kecelakaan kapal bertujuan untuk melakukan penyelidikan atau pengusutan suatu peristiwa kecelakaan kapal yang dilakukan oleh Pejabat Pemerintah yang berwenang untuk mengetahui sebab-sebab terjadinya kecelakaan kapal, dan untuk mengetahui pihak mana yang bertanggung jawab atas terjadinya kecelakaan kapal tersebut.

Terhadap kapal ikan, bila diketahui ada kapal lain (kapal niaga) menubruk jaring dari pada kapal ikan tersebut atau menubruk kapal ikan itu sendiri hingga mengalami kerusakan dan kemudian melaporkan kejadian tersebut ke kantor Syahbandar Belawan,maka kapal lain yang menubruknya bertanggung jawab atas perbuatannya itu dengan mengganti kerugian dari pemilik kapal tersebut. Penggantian kerugian 
tersebut dapat berupa pembayaran sejumlah uang yang ditaksir besarnya kerugian yang diderita kapal ikan tersebut, yang dibebankan oleh pemilik kapal yang menubruk kapal ikan tersebut.Demikianlah bentuk tanggung jawab hukum yang selama ini dilaksanakan oleh Syahbandar Belawan.

Berkaitan dengan hal tersebut di atas, Syahbandar di Pelabuhan Perikanan sendiri tidak memiliki kewenangan untuk melakukan pemeriksaan kecelakaan kapal ikan tersebut. Oleh karena di dalam undangundang perikanan sendiri tidak mengatur secara khusus tentang kecelakaan kapal, undang-undang hanya menyebutkan melaksanakan bantuan pencarian dan penyelamatan apabila terjadi kecelakaan kapal ikan sesuai Pasal 42 ayat (2) huruf k Undang-undang No. 45 Tahun 2009 dan Pasal 5 huruf $n$ Peraturan Menteri Kelautan dan Perikanan No. 3/PERMEN-KP/2013. Ketentuan kedua pasal tersebut juga merupakan bagian yang diadopsi dari undang-undang pelayaran yaitu pada ketentuan Pasal 208 UU No. 17 Tahun 2008.

Sebenarnya penerbitan SPB kapal ikan itu tidak hanya merupakan proses administrasi saja, tetapi masih ada tanggung jawab hukum yang harus dilaksanakan dalam melaksanakan pengawasan keselamatan pelayaran kapal ikan yang tidak dapat dilakukan oleh Syahbandar di Pelabuhan Perikanan berkaitan dengan kompetensi (kewenangan). Karena hal tersebut merupakan domain dari Syahbandar Direktorat Jenderal Perhubungan Laut.

\section{Penutup}

\section{A. Kesimpulan}

1. Harmonisasi pengaturan tentang kompetensi (kewenangan) dalam Penerbitan Surat Persetujuan Berlayar Kapal Ikan di Pelabuhan Belawan ditinjau dari UU No. 17 Tahun 2008 tentang Pelayaran dan UU No. 45 Tahun 2009 tentang Perikanan, khususnya ketentuan Pasal 42 UU No. Tahun 2009 terkait kewenangan Syahbandar dalam penerbitan Surat Persetujuan Berlayar, bahwa terjadi ketidakharmonisan (disharmonisasi) peraturan perundang-undangan antara UU No. 17 Tahun 2008 dengan UU No. 45 Tahun 2009, serta termasuk peraturan di bawahnya seperti Peraturan Menteri Perhubungan Nomor :PM. 82 Tahun 2014 yang merupakan pengganti dari Peraturan Menteri Perhubungan Nomor: KM. 01 Tahun 2010 dan Peraturan Menteri Perhubungan Nomor: PM. 23 Tahun 2014 tentang Perubahan atas Peraturan Menteri Perhubungan Nomor: KM. 01 Tahun 2010 Tentang Tata Cara Penerbitan Surat Persetujuan Belrayar (Port Clearance) terhadap UU No. 17 Tahun 2008 dimana pada Peraturan Menteri No. PM. 82 Tahun 2014 Pasal 2 ayat (3) terjadi pertentangan dengan perintah Undang-undang di dalam Pasal 207 ayat (1), dan juga di dalam konsideran Peraturan Menteri Perhubungan No. PM. 82 Tahun 2014 tersebut juga memasukkan Undangundang Nomor 45 tahun 2009 tentang Perikanan sebagai salah satu unsur penerbitan Permenhub No. PM. 82 Tahun 2014 tersebut. Selanjutnya Peraturan Menteri Kelautan dan Perikanan terhadap UU No. 45 Tahun 2009 juga saling bertentangan. Sebab esensi dari UU No. 45 Tahun 2009 seharusnya hanya mengatur tentang perikanan saja yang di dalamnya tidak mengatur tentang keselamatan pelayaran kapal perikanan, sedangkan esensi dari UU. No. 17 Tahun 2008 secara jelas telah mengatur tentang keselamatan pelayaran, namun dari segi sinergitas antara Permenhub No. PM. 82 Tahun 2014 dengan Permen Kelautan dan Perikanan No. 3/PERMEN-KP/2013, terjadi sinergitas.

2. Keabsahan (legitimasi) Surat Persetujuan Berlayar yang diterbitkan oleh Syahbandar Perikanan di Pelabuhan Belawan, bahwa khusus penerbitan Surat Persetujuan Berlayar (SPB) kapal ikan yang diterbitkan oleh Syahbandar di Pelabuhan Perikanan adalah sah berdasarkan Undangundang No. 45 Tahun 2009 dan 
Peraturan Menteri Kelautan dan Perikanan No. 3/PERMEN-KP/2013, tetapi ditinjau dari Undang-undang No. 12 Tahun 2011 tentang Pembentukan Peraturan Perundangundangan sangatlah bertentangan; dan bertentangan dengan azas hukum pembentukan peraturan perundang-undangan (legal drafting). Sama halnya dengan Undang-undang No. 17 Tahun 2008 yang bertentangan dengan Peraturan Menteri Perhubungan No. KM. 82 Tahun 2014 yang memberikan kewenangan kepada Kementerian Kelautan dan Perikanan dalam hal penerbitan Surat Persetujuan Berlayar (SPB), yang menyebabkan dualisme aturan hukum di Indonesia terkait keabsahan (legitimasi) penerbitan SPB tersebut.

3. Tanggung Jawab Hukum Syahbandar di Pelabuhan Perikanan Belawan terkait dengan Penerbitan Surat Persetujuan Berlayar Kapal Ikan, bahwa Undang-undang No. 45 Tahun 2009 hingga Peraturan Menteri Kelautan dan Perikanan No. 3/PERMEN-KP/2013 terbatas hanya kepada pengaturan tentang pemberian bantuan dan keselamatan apabila terjadi kecelakaan kapal, tetapi Undang-undang No. 17 Tahun 2008 beserta peraturan pelaksananya mengatur tentang tanggung jawab hukum atas setiap kejadian terhadap semua kapal (termasuk kapal penangkap ikan) terkait kecelakaan kapal baik kapal perikanan sendiri maupun kapalkapal lainnya.

\section{B. Saran}

1. Perlu ditinjau kembali dan dilakukan revisi terhadap Undang-undang No. 45 Tahun 2009 khususnya pada pasal 42 sehubungan dengan kewenangan Syahbandar di Pelabuhan Perikanan tentang Keselamatan Pelayaran dan Penerbitan Surat Persetujuan Berlayar beserta peraturan pelaksananya, gunakepastian hukum di Indonesia dan supremasi hukum, sehingga tidak terjadi tumpang tindih (overlapping) diantara peraturan hukum (peraturan perundang-undangan) yang berlaku.

2. Dalam pembentukan Peraturan Perundang-undangan terkait penerbitan Surat Persetujuan Berlayar (SPB) kapal ikan, seharusnya memperhatikan asasasas pembentukan peraturan perundang-undangan, guna menghindari kerancuan dan ketidakselarasan diantara peraturan perundang-undangan yang diterbitkan. Seperti isi Pasal 42 Undang-undang No. 45 Tahun 2009 yang sebagian mengadopsi isi Pasal 207, 208 dan Pasal 219 dari Undangundang No. 17 Tahun 2008. Dengan demikian sebaiknya diajukan uji materi terhadap Pasal 42 UU. No. 45 Tahun 2009 tentang Perubahan Atas UU. No. 31 Tahun 2004 tentang Perikanan, terkait dengan tugas dan wewenang Syahbandar di Pelabuhan Perikanan, khususnya dalam rangka penerbitan Surat Persetujuan Berlayar (SPB) kapal ikan.

3. Dalam hal tanggung jawab hukum yang diberikan kepada Syahbandar di Pelabuhan Perikanan hanya sebatas tanggung jawab administratif, sehingga terhadap para pengusaha kapal perikanan di Pelabuhan Belawan hanya menerima kewajiban yang harus dipenuhinya selaku subjek hukum, sedangkan hak-haknya diabaikan (tidak diatur dalam suatu peraturan perundangundangan).

4. Sebaiknya anggota legislatif harus lebih teliti dalam pembentukan undang-undang, agar tidak terjadi dikotomi hukum di Indonesia. Dalam pembuatan dan pembentukan peraturan menteri seharusnya tidak bertentangan dengan undangundang yang berlaku, sehingga supremasi hukum di Indonesia dapat ditegakkan. 


\section{DAFTAR PUSTAKA}

\section{A. Buku}

Anonim. Buku Pendidikan dan Pelatihan Marine Inspector Tipe A tentang Perangkat Radio Kapal, Direktorat Perkapalan dan Kepelautan. Ditjen Hubla. Jakarta.

Amanullah, M., "Aproaches to Metodology of Harmonitation: Principles to Be Followed in Harmonitation of Shari'ah and Man-Made Law", International Conference on Harmonitation of Shari'ah and Civil Law 2, Kuala Lumpur 29-30 Juni 2005.

Amiruddin dan Asikin, Z.H. 2006.Pengantar Metode Penelitian Hukum. Jakarta: Raja Grafindo Persada.

Asshiddiqie, J. dan M. Ali Safa'at. 2012. Teori Hans Kelsen tentang Hukum. Jakarta: Konstitusi Press.

Asshiddiqie, J. 2014. Perihal Undang-Undang. Jakarta: Rajawali Pers.

Asofa, Burhan. 2004. Metode Penelitian Hukum. Jakarta: Rineka Cipta.

Barus, Utary M. Penerapan Hukum Perjanjian Islam Bersama Hukum Perjanjian menurut KUHPerdata dalam Akad Perbankan Syari'ah di Indonesia.Disertasi.Dalam

Mohammad Hashim Kamali, "Shariah and Civil Law", International Conference on Harmonitation of Shari'ah and Civil Law 2, Kuala Lumpur 20-210ktober 2003.

Busroh, Abu Daud dan Abubakar Busro. 1985. Asas-Asas Hukum Tata Negara. Jakarta: Ghalia Indonesia.

Ediwarman. 2011. Monograf. Metode Penelitian Hukum (Panduan Penulisan Tesis dan Disertasi), Medan. Ibrahim, Jhony. 2006. Teori dan Penelitian Hukum Normatif. Malang: Bayumedia Publishing.

Indrati, Maria F. 2013. Ilmu PerundangUndangan. Yogyakarta: Kanisius.

Istopo, Penuntun Peraturan Pencegahan Tuburukan di Laut 1972. Jakarta: Kesatuan Pelaut Indonesia.

Lubis, M. Solly.1999. Filsafat Ilmu dan Penelitian. Bandung: Mandar Maju.

Marzuki, Peter Mahmud. 2007. Penelitian Hukum. Jakarta: Kencana Prenada Group.
Marzuki, Peter Mahmud 2013.Pengantar Ilmu Hukum. Edisi Revisi. Cetakan ke5. Jakarta: Kencana PrenadaMedia Group.

Purbacaraka, Purnadi dan Soerjono Soekanto. 1979. Perundangundangan dan Yurisprudensi. Bandung: Alumni.

Rosadhy, Sammy. 1981. Pencegahan Polusi di Laut.

Rosadhi, Sammy. Pedoman tentang Aplikasi IMO - Code Manajemen Keselamatan Internasional (ISM-Code).

Salim, Usman.Intisari Keseimbangan Kapal. Jakarta, 1991.

Sidharta, Bernard Arief. 1999. Refleksi tentang Struktur Ilmu Hukum. Bandung: Mandar Maju.

Soekanto, Soerjono. Pengantar Penelitian Hukum. Jakarta: UI Press, 1996.

Soekanto, Soerjono dan Sri Mamuji. 2003. Penelitian Hukum Normatif: Suatu Tinjauan Singkat. Jakarta: Raja Grafindo Persada.

Susantono, Bambang. 2013. Transportasi dan Investasi Tantangan dan Perspektif Multidimensi.Jakarta: Kompas.

Suryono, dan Isnaini, (2009), Tuntutan Ganti Rugi atas Kehilangan Barang di dalam Container oleh Pengguna Jasa Terminal Petikemas Belawan PT (Persero) Pelabuhan Indonesia I, Mercatoria, 2 (2): 128-140

Syarif, Amiroeddin. 1997. PerundangUndangan Dasar, Jenis dan Teknik Pembuatannya. Cetakan Kedua. Jakarta: Rineka Cipta.

Thaib, D., Jazim Hamidi, dan Ni'matul Huda. 2006. Teori dan Hukum Konstitusi. Jakarta: RajaGrafindo Persada.

Yuliandri. 2013. Asas-Asas Pembentukan Peraturan Perundang-undangan Yang Baik. Jakarta: Rajawali Pers.

\section{B. Peraturan Perundang-undangan}

Kitab Undang-Undang Hukum Dagang (KUHD) Indonesia

Undang-Undang Republik Indonesia No. 21 Tahun 1992 tentang Pelayaran

Undang-Undang Republik Indonesia No. 17 Tahun 2008 tentang Pelayaran 
Undang-Undang Republik Indonesia No. 45 Tahun 2009 tentang Perubahan Atas Undang-Undang No. 31 Tahun 2004 tentang Perikanan

Peraturan Pemerintah Nomor 1 Tahun 1998 tentang Pemeriksaan Kecelakaan Kapal

Peraturan Pemerintah Nomor 51 Tahun 2002 tentang Perkapalan

Peraturan Menteri Perhubungan Nomor KM. 55 Tahun 2006 tentang Tata Cara Pemeriksaan Kecelakaan kapal

Peraturan Menteri Perhubungan No.KM. 01 Tahun 2010 tentang Tata Cara Penerbitan Surat Persetujuan Berlayar.

Peraturan Menteri Perhubungan No.KM. 23 Tahun 2014 tentang Perubahan Atas Peraturan Menteri Perhubungan No. KM. 01 Tahun 2010 tentang Tata Cara Penerbitan Surat Persetujuan Berlayar.

Peraturan Menteri Kelautan dan Perikanan 3/PERMEN-KP/2013 tentang Kesyahbandaran di Pelabuhan Perikanan.
Peraturan Menteri Perhubungan No.PM. 13 Tahun 2012 tentang Pendaftaran dan Kebangsaan Kapal.

Peraturan Menteri Perhubungan No.PM. 82 Tahun 2014 tentang Tata Cara Penerbitan Surat Persetujuan Berlayar.

SOLAS Convention 74 Edisi Konsolidasi Tahun 2004

\section{Internet}

Kusnu Goesniadhie S. Harmonisasi Hukum Dalam Perspektif Perundangundangan (Lex Specialis Suatu Masalah), 2006 dalam http://kgsc.files.wordpress.com/har monisasi-hukum-lex-specialis-suatumasalah.ppt.html.

Rara Novianti, dalam http://www.academia.edu/Transpor tasi Antar Pulau.html 